\title{
Chlorophyll fluorescence, yield and yield components of bread wheat affected by phosphate bio-fertilizer, zinc and boron under late-season heat stress
}

\author{
H.R. EISVAND ${ }^{*,+}$, H. KAMAEI, and F. NAZARIAN \\ Department of Agronomy and Plant Breeding, Faculty of Agriculture, Lorestan University, Khurramabad, \\ P.O. Box $465^{*}$, Iran
}

\begin{abstract}
We examined effects of late-season heat stress (L-SHS) on chlorophyll (Chl) fluorescence parameters and yield of bread wheat as well as roles of phosphate bio-fertilizer (PB-F) and $\mathrm{Zn}$ and B to compensate for the likely effects of heat stress. Factors were planting date (21 November and 5 January to coincide with grain filling to L-SHS) as the main factor, no inoculation (control) and inoculation of the seeds with PB-F as the sub-factor, and foliar application of water (control), $\mathrm{Zn}, \mathrm{B}$, and $\mathrm{Zn}+\mathrm{B}$ as $3 \mathrm{~L} \mathrm{ha}^{-1}$ as sub-sub factor. Results revealed that L-SHS reduced maximal quantum yield of PSII photochemistry, effective quantum yield of PSII photochemistry, efficiency of PSII in the light-adapted state, and the grain yield. Moreover, L-SHS increased the nonphotochemical quenching. The PB-F mitigated the effects of L-SHS on Chl fluorescence, yield, and yield components. Among nutrients, the combined $\mathrm{Zn}+\mathrm{B}$ was more effective in reducing the effects of L-SHS than that of $\mathrm{Zn}$ and B alone. Nevertheless, there was an interaction between foliar nutrients application and PB-F, suggesting that $\mathrm{Zn}$ application alone had a profound influence on improving $\mathrm{Chl}$ fluorescence parameters and increased yield in combination with PB-F.
\end{abstract}

Additional key words: photosynthesis; plant nutrition; Triticum aestivum L.

\section{Introduction}

Wheat (Triticum aestivum L.), as a major source of human food, is grown in a vast area of cultivated lands mostly located at altitudes from a few meters to more than 3,000 m a. s. 1. (Ahmed and Farooq 2013). High temperature and drought are two major environmental factors limiting the growth and productivity of wheat (Prasad et al. 2011). Heat stress affects many cellular processes in plants, resulting in physiological, morphological, and biochemical changes (Zhang et al. 2016). Terminal or late heat stress during the last phases of wheat development, especially in booting, heading, anthesis and grain filling stages of the spring, is considered one of the major environmental constraints that drastically reduces grain yield and yield components of wheat in Khouzestan province and other warm and dry regions of Iran (Modhej et al. 2008). For optimum growth and yield, wheat plants need phosphorus $(\mathrm{P})$ as a macronutrient and its role irreplaceable (Mohammadi 2012). Phosphate biofertilizers (PB-F), bacteria, such as Bacillus and Pseudomonas, increase soil soluble $\mathrm{P}$ by secreting organic acids and phosphatase enzyme (Ehteshami et al. 2007). The supply of $\mathrm{P}$ promotes the development of roots, flowers, and fruits formation, the rate of plant maturation, the efficiency and quality of crops, and the resistance to both biotic and abiotic environmental factors (Mohammadi 2012). Most of the Iranian soils, have a high $\mathrm{pH}$ and calcareous nature (Abdoli et al. 2014) and micronutrients solubility in these soils is low (Mousavi et al. 2007). It is believed that micronutrients foliar application is more effective in controlling deficiency problem than soil application (Torun et al. 2001). Micronutrients significantly affect dry matter, grain yield, and straw yield in wheat (Asad and Rafique 2000). Zinc is a ubiquitous micronutrient. It is required as a structural and functional component of many enzymes and proteins, and increases the yield and yield components of wheat (Jafari Moghadam et al. 2012). Boron is essential for pollen viability, flowering, fruiting, and seed production. As a micronutrient, it plays

Received 11 May 2017, accepted 7 February 2018, published as online-first 21 June 2018.

${ }^{+}$Corresponding author; e-mail: eisvand.hr@lu.ac.ir

Abbreviations: Chl - chlorophyll; $\mathrm{FA}$ - foliar application of $\mathrm{Zn}$ and $\mathrm{B} ; \mathrm{F}_{\mathrm{v}} / \mathrm{F}_{\mathrm{m}}$ - maximal quantum yield of PSII photochemistry; $\mathrm{F}_{\mathrm{v}}{ }^{\prime} / \mathrm{F}_{\mathrm{m}}{ }^{\prime}$ - efficiency of PSII in the light-adapted state; LPD - late planting date; L-SHS - late-season heat stress; N-HS - no heat stress; NPQ - nonphotochemical quenching; OPD - optimum planting date; PB-F - phosphate bio-fertilizer; ROS - reactive oxygen species; $\Phi_{\text {PSII }}$ - effective quantum yield of PSII photochemistry. 
a vital role in nitrogen metabolism, hormonal action, and cell division (BARI 2006). Boron foliar application at reproductive stage improves the grain yield of wheat (Ali et al. 2009). Boron can increase antioxidant activities of plants, thereby alleviating reactive oxygen species (ROS) damage induced by heat stress (Waraich et al. 2011). The role of $\mathrm{B}$ in regulation of the gene expression or regulation of the activity of certain antioxidant enzymes, e.g., superoxide dismutase and catalase, has been proved (Keles et al. 2011).

Nowadays, Chl fluorescence has been used as an indicator of the level of stress. The advantage of this technique over many other techniques is that it provides rapid and nondestructive measures. Graham and McDonald (2001) showed that the decline in maximal quantum yield of PSII photochemistry $\left(\mathrm{F}_{\mathrm{v}} / \mathrm{F}_{\mathrm{m}}\right)$ due to high temperature can be reduced by elevated $\mathrm{Zn}$ fertilization, at least in a $\mathrm{Zn}$ inefficient wheat genotype. High temperature reduces effective quantum yield of PSII photochemistry $\left(\Phi_{\text {PSII }}\right)$ and nonphotochemical quenching (NPQ) (Hassan 2006). The $\Phi_{\text {PSII }}$ reflects the fraction of radiation absorbed by PSII that is used in photochemistry (Demmig-Adams and Adams 1992) and it is a good indicator of the effects of environmental stress on photosynthesis. PSII plays an important role in the response of plants to environmental stresses and it is a very sensitive component of the photosynthetic apparatus (Yordanov et al. 2000). Chl fluorescence parameters, such as minimal $\left(\mathrm{F}_{0}{ }^{\prime}\right)$, maximal $\left(\mathrm{F}_{\mathrm{m}}{ }^{\prime}\right)$, variable

\section{Materials and methods}

Experimental site: A field experiment was performed during 2015-2016 in Ramhormoz city, Khouzestan province, Iran. Site altitude was $160 \mathrm{~m}$ above sea level $\left(31^{\circ} 16^{\prime} \mathrm{N}, 49^{\circ} 37^{\prime} \mathrm{E}\right)$. Farm soil was silty clay and alkaline
$\left(\mathrm{F}_{\mathrm{v}}{ }^{\prime}\right)$, and steady-state $\left(\mathrm{F}_{\mathrm{s}}\right)$ fluorescence yields, $\mathrm{F}_{\mathrm{v}} / \mathrm{F}_{\mathrm{m}}$, $\mathrm{F}_{\mathrm{v}}{ }^{\prime} / \mathrm{F}_{\mathrm{m}}{ }^{\prime}, \Phi_{\mathrm{PSII}}$, and NPQ serve as indicators of plant stress and have been utilized to assess the plant nutrient status and health (Netto et al. 2005). Under stress conditions, such as nutrient stress, decline in $\mathrm{CO}_{2}$ assimilation also reduces the consumption of the chemical energy created in the light reaction of photosynthesis, which leads to the overexcitation of PSII reaction center due to continuing photon absorption by Chl molecules (Singh and Reddy 2016). This excess energy must be dissipated for optimum performance of photosystems and to avoid photoinhibition. Plants possess mechanisms to dissipate the excess excitation energy as heat, re-emite as Chl fluorescence or by nonradiative mechanisms (Ivanov et al. 2008). Singh and Reddy (2016) suggested the decrease in Chl concentration as a mechanism to avoid excessive light harvesting to protect PSII from photodamage under P deficiency. Graham and McDonald (2001) revealed that the decline in $\mathrm{F}_{\mathrm{v}} / \mathrm{F}_{\mathrm{m}}$ due to high temperature can be lowered by elevated $\mathrm{Zn}$ fertilization, at least in a $\mathrm{Zn}$-inefficient wheat genotype. In addition, Guidi et al. (2011) reported an increase in Chl fluorescence parameters, such as $\mathrm{F}_{\mathrm{v}} / \mathrm{F}_{\mathrm{m}}, \Phi_{\mathrm{PSII}}$, and NPQ, as a result of boron application. The aim of this study was to evaluate the effect of PB-F and foliar application of $\mathrm{Zn}$ and $\mathrm{B}$ to reduce the harmful effects of L-SHS on Chl fluorescence parameters, yield, and yield components of common bread wheat.

\begin{tabular}{lllllllllllll}
\hline $\begin{array}{l}\mathrm{B} \\
{\left[\mathrm{mg} \mathrm{kg}^{-1}\right]}\end{array}$ & $\begin{array}{l}\mathrm{Zn} \\
{\left[\mathrm{mg} \mathrm{kg}^{-1}\right]}\end{array}$ & $\begin{array}{l}\mathrm{Fe} \\
{\left[\mathrm{mg} \mathrm{kg}^{-1}\right]}\end{array}$ & $\begin{array}{l}\mathrm{Cu} \\
{\left[\mathrm{mg} \mathrm{kg}^{-1}\right]}\end{array}$ & $\begin{array}{l}\text { Soil } \\
\text { texture }\end{array}$ & $\begin{array}{l}\text { Clay } \\
{[\%]}\end{array}$ & $\begin{array}{l}\text { Silt } \\
{[\%]}\end{array}$ & $\begin{array}{l}\text { Sand } \\
{[\%]}\end{array}$ & $\begin{array}{l}\mathrm{K} \\
{\left[\mathrm{mg} \mathrm{kg}^{-1}\right]}\end{array}$ & $\begin{array}{l}\mathrm{P} \\
{\left[\mathrm{mg} \mathrm{kg}^{-1}\right]}\end{array}$ & $\begin{array}{l}\mathrm{O} . \mathrm{C} \\
{[\%]}\end{array}$ & $\begin{array}{l}\mathrm{pH} \\
\begin{array}{l}\mathrm{E} . \mathrm{C} \\
{\left[\mathrm{ds} \mathrm{m}^{-1}\right]}\end{array}\end{array}$ \\
\hline 0.71 & 0.63 & 2.8 & 0.9 & Silty clay 47 & 42 & 11 & 140 & 18.6 & 0.92 & 7.6 & 5.8 & \\
\hline
\end{tabular}

The available $\mathrm{P}$ and $\mathrm{K}$ were determined according to Olsen et al. (1954) and normal and neutral ammonium acetate methods, respectively (Page et al. 1982). The available B was determined by the azomethine-H method (Wolf 1974), and the available $\mathrm{Zn}, \mathrm{Cu}$, and $\mathrm{Fe}$ were determined by extraction method with diethylenetriamine pentaacetic
(pH 7.64) with $0.92 \%$ organic carbon, $18.6 \mathrm{mg}$ (available P) $\mathrm{kg}^{-1}$, and $140 \mathrm{mg}$ (available $\left.\mathrm{K}\right) \mathrm{kg}^{-1}$. Soil physical and chemical properties of experimental location are shown in the table:

\begin{tabular}{llllll}
\hline \multirow{2}{*}{$\begin{array}{l}\text { Month } \\
\text { Mean of air temperature }\left[{ }^{\circ} \mathrm{C}\right]\end{array}$} & \multicolumn{2}{c}{ Precipitation [mm] } & RH [\%] \\
\hline November & 31.5 & 17.2 & 24.3 & 20.7 & 42 \\
December & 25.3 & 11.1 & 18.2 & 64.4 & 59 \\
January & 18.1 & 8.8 & 13.4 & 57.7 & 67 \\
February & 19.3 & 9.1 & 14.2 & 49.7 & 62 \\
March & 24.7 & 12.2 & 19.8 & 40.4 & 52 \\
April & 32.5 & 16.7 & 24.6 & 29.4 & 43 \\
May & 38.1 & 23.2 & 30.6 & 29.6 & 43 \\
\hline
\end{tabular}

acid (DTPA) (Sparks et al. 1996). The amounts of K and other available nutrients were determined before adding any fertilizer to the soil. Temperature, precipitation and relative humidity during the experimental period are shown in the table: 
The average minimum and maximum temperature at the test site during the grain filling period for optimum and late planting dates were 18 and $32^{\circ} \mathrm{C}$, and 22 and $38^{\circ} \mathrm{C}$, respectively. During the grain filling and maturity stages, the mean of the canopy temperature depression for the LPD in all applied treatments decreased by about 3 and $5^{\circ} \mathrm{C}$ compared to the OPD, respectively.

Experimental design, treatments and plant material: The field experiment was arranged in a split-plot factorial design based on randomized complete blocks with 16 treatments and 3 replications. Experimental treatments included optimum planting date (OPD) (21 November) and the late planting date (LPD) (5 January) to coincide with the grain filling stage to L-SHS (Radmehr 1997) as the main factor, PB-F [no inoculation (control) and inoculation of the seeds with PB-F] as the sub-factor, and four levels of foliar application of water (control), $\mathrm{Zn}[3 \mathrm{~L}$ $\mathrm{ha}^{-1}$ of liquid Zn-EDTA chelate from ZARAFSHAN Co., containing $7.5 \%$ of $\mathrm{Zn}$; as $3: 1,000(\mathrm{v} / \mathrm{v})$ in water], B [3 $\mathrm{L} \mathrm{ha}^{-}$ ${ }^{1}$ of boric acid from ZARAFSHAN Co., containing $5 \%$ of $\mathrm{B}$, as 3:1,000 (v/v) in water], and $\mathrm{Zn}\left(3 \mathrm{~L} \mathrm{ha}^{-1}\right)+\mathrm{B}\left(3 \mathrm{~L} \mathrm{ha}^{-1}\right)$, as sub-sub factor. Total applied $\mathrm{Zn}$ and $\mathrm{B}$ in foliar application was $675 \mathrm{~g}($ pure $\mathrm{Zn}) \mathrm{ha}^{-1}$ and $450 \mathrm{~g}$ (pure B) ha 1 . This amount of fertilizers was sprayed three times at tillering, booting, and anthesis stages to the wheat plants. Treatments were applied to Aflak wheat cultivar (Debeira) which was recommended for planting in warm and dry areas such as the site of our experiment.

Each plot had seven rows of planting. The row spacing was $20 \mathrm{~cm}$, and row length was $3 \mathrm{~m}$. The seeds were sown at a depth of $3 \mathrm{~cm}$ by hand with a planting density of 400 plants $\mathrm{m}^{-2}$. Before planting, seed inoculation was performed with the package content of $100 \mathrm{~g}$ of biofertilizer (Barvar 2) containing phosphate solubilizing bacteria such as Bacillus and Pseudomonas. Barvar 2 is a phosphate bio-fertilizer designed for all agricultural purpose, all types of crops and trees that reduce the need for phosphate chemical fertilizer for at least $50 \%$. Weeds were manually controlled in all treatments (Ehteshami et al. 2007). Fertilizer recommendations based on soil analysis results were applied including $300 \mathrm{~kg}$ (sulfur) ha, $150 \mathrm{~kg}$ (potassium sulfate) $\mathrm{ha}^{-1}$, and $350 \mathrm{~kg}$ (urea) $\mathrm{ha}^{-1}$. Sulfur, potassium, and one-third of urea fertilizers were applied at sowing and the remaining part was applied during the beginning of stem elongation and flowering stages. Irrigation, fertilization, and weeds, pests, and diseases control were performed regularly to avoid any stress except the L-SHS. The water requirement for irrigation estimated about $550 \mathrm{~mm}$ using equation 1 (Gholinezhad et al. 2009), which supplied about 230 and $140 \mathrm{~mm}$ of it for OPD and LPD by rainfall, respectively.

$\mathrm{V}=\left[(\mathrm{FC}-\theta \mathrm{m}) \times \rho \mathrm{m} \times \mathrm{D}_{\text {root }} \times \mathrm{A}\right] / \mathrm{IE}$

where, $\mathrm{V}$ is irrigation water volume $(\mathrm{mm}) ; \mathrm{FC}$ is field capacity; $\theta \mathrm{m}$ is soil mass moisture percentage; $\rho \mathrm{m}$ is soil external specific density $\left(\mathrm{g} \mathrm{cm}^{-3}\right) ; \mathrm{D}_{\text {root }}$ is root develop- ment depth (m); A irrigated area $\left(\mathrm{m}^{2}\right)$; and IE is irrigation efficiency. Irrigation was carried out by surface (furrow) method and at germination, emergence, tillering, stemming, heading, flowering, and seed filling stages and when the average soil moisture reached less than $50 \%$ of the available moisture content. For determining soil moisture, samples were taken from depth of $0-30$ and 30 $60 \mathrm{~cm}$. Then moisture percentage was determined by pressure plate (armfield CAT.REF: FEL13B-1 Serial Number: 6353 A 24S98) (Gholinezhad et al. 2015). The harvesting time for OPD and LPD were 21 April and 7 May, respectively. During this period of about $17 \mathrm{~d}$, the air temperature increased by about $6^{\circ} \mathrm{C}$. It was also observed that from the grain filling stage to the maturity, the number of days with a temperature higher than $32^{\circ} \mathrm{C}$ at LPD was about $17 \mathrm{~d}$; it was about $1 \mathrm{~d}$ during OPD.

Chl fluorescence: Chl fluorescence was measured with a portable photosynthetic efficiency analyser (PEA, Hansantech Instrumental, Hardwick, Norfolk, UK). Flag leaves were dark-adapted for $30 \mathrm{~min}$ in leaf clips before measurements. Chl fluorescence parameters, such as $\mathrm{F}_{\mathrm{v}} / \mathrm{F}_{\mathrm{m}}, \Phi_{\mathrm{PSII}}, \mathrm{F}_{\mathrm{v}}{ }^{\prime} / \mathrm{F}_{\mathrm{m}}{ }^{\prime}$, and NPQ were calculated according to van Kooten and Snel (1990) and using the following equations:

$\mathrm{F}_{\mathrm{v}} / \mathrm{F}_{\mathrm{m}}=\left(\mathrm{F}_{\mathrm{m}}-\mathrm{F}_{0}\right) / \mathrm{F}_{\mathrm{m}}$
$\Phi_{\mathrm{PSII}}=\left(\mathrm{F}_{\mathrm{m}}-\mathrm{F}_{\mathrm{t}}\right) / \mathrm{F}_{\mathrm{m}}{ }^{\prime}$
$\mathrm{F}_{\mathrm{v}}{ }^{\prime} / \mathrm{F}_{\mathrm{m}}{ }^{\prime}=\left(\mathrm{F}_{\mathrm{m}}{ }^{\prime}-\mathrm{F}_{0}{ }^{\prime}\right) / \mathrm{F}_{\mathrm{m}}{ }^{\prime}$
$\mathrm{NPQ}=\left(\mathrm{F}_{\mathrm{m}}-\mathrm{F}_{\mathrm{m}}{ }^{\prime}\right) / \mathrm{F}_{\mathrm{m}}{ }^{\prime}$

where, $F_{v} / F_{m}$ is the maximum quantum efficiency of PSII in the dark-adapted state; $F_{m}$ is the maximum fluorescence (in the dark-adapted leaf); $\mathrm{F}_{0}$ is the minimum fluorescence (dark); $\mathrm{F}_{\mathrm{v}}$ is the variable fluorescence (dark) $\left(\mathrm{F}_{\mathrm{m}}-\mathrm{F}_{0}\right) ; \Phi_{\text {PSII }}$ is the quantum efficiency of PSII; $F_{t}$ is the fluorescence emitted by the leaves adapted to light; $F_{m}$ ' is the maximum fluorescence (light); $\mathrm{F}_{\mathrm{v}}{ }^{\prime} / \mathrm{F}_{\mathrm{m}}{ }^{\prime}$ is the maximum quantum efficiency of PSII in the light-adapted state; $\mathrm{F}_{0}{ }^{\prime}$ is the minimum fluorescence (light); $\mathrm{F}_{\mathrm{v}}{ }^{\prime}$ is the variable fluorescence (light) $\left(\mathrm{F}_{\mathrm{m}}{ }^{\prime}-\mathrm{F}_{0}{ }^{\prime}\right)$; and NPQ is the nonphotochemical quenching. Measurements were taken between 10:00 14:00 $\mathrm{h}$ from $10 \mathrm{flag}$ leaves at the grain filling stage. During the measurement of $\mathrm{Chl}$ fluorescence parameters, the air temperature for optimum and late dates were 28 and $37^{\circ} \mathrm{C}$, respectively.

Grain yield and yield components: The inner two rows of each plot were harvested to estimate the grain yield at maturity, and a sample of one square meter was obtained to determine the number of spikes $\mathrm{m}^{-2}$, number of grain per spike, 1,000-grain mass, and grain yield.

Statistical analysis: Analysis of variance $(A N O V A)$ was performed using general linear model (GLM) procedure of statistical analysis system (SAS version: 9.1). The means were analyzed using the least significant difference (LSD) method at $P=0.05$ (LSD 0.05). 


\section{Results}

Grain yield and its compoments

Number of spikes per area: L-SHS, PB-F, and foliar application treatments had significant effects on the number of spikes $\mathrm{m}^{-2}$ (Table 1). L-SHS significantly reduced the number of spikes by $13 \%$ compared to N-HS. However, seed inoculation with PB-F and foliar application of $\mathrm{Zn}$ and $\mathrm{B}$ significantly reduced the harmful effects of L-SHS on the number of spikes by 5.9 and $5 \%$, respectively, compared with control (Tables 1,2). The maximum and minimum values were obtained after the combined treatments, namely PB-F $+\mathrm{Zn}$ foliar application under N-HS, and non-inoculation of the seeds with PB-F + water foliar application under L-SHS (Table 2).

Table 1. Analysis of variance for yield, yield components and chlorophyll fluorescence parameters, such as $F_{v} / F_{m}-$ maximal quantum yield of PSII photochemistry; $\Phi_{\text {PSII }}$ - effective quantum yield of PSII photochemistry; $\mathrm{F}_{\mathrm{v}}{ }^{\prime} / \mathrm{F}_{\mathrm{m}}{ }^{\prime}$ - efficiency of PSII in the light-adapted state; and NPQ - nonphotochemical quenching of bread wheat affected by PB-F - phosphate bio-fertilizer and FA of Zn and B - foliar application of zinc and boron under L-SHS - late-season heat stress. ns, ${ }^{*}$, and ${ }^{* *}$ - not significant, significance at the 0.05 and 0.01 probability level, respectively.

\begin{tabular}{|c|c|c|c|c|c|c|c|c|c|}
\hline $\begin{array}{l}\text { Sources } \\
\text { Changes }\end{array}$ & $\mathrm{DF}$ & $\begin{array}{l}\text { Number of } \\
\text { spikes }\left[\mathrm{m}^{-2}\right]\end{array}$ & $\begin{array}{l}\text { Number of } \\
\text { grain spike }{ }^{-1}\end{array}$ & $\begin{array}{l}1,000 \text { - grain } \\
\text { mass }\end{array}$ & Grain yield & $\mathrm{F}_{\mathrm{v}} / \mathrm{F}_{\mathrm{m}}$ & $\Phi_{\text {PSII }}$ & $\mathrm{F}_{\mathrm{v}}^{\prime} / \mathrm{F}_{\mathrm{m}}{ }^{\prime}$ & NPQ \\
\hline Block & 2 & $4.32^{\mathrm{ns}}$ & $0.092^{\text {ns }}$ & $0.672^{\mathrm{ns}}$ & $234.3^{\mathrm{ns}}$ & $3 \times 10^{-6 n s}$ & $4 \times 10^{-6 \mathrm{~ns}}$ & $3 \times 10^{-6 \mathrm{~ns}}$ & $2 \times 10^{-6 \mathrm{~ns}}$ \\
\hline L-SHS & 1 & $50,659.81^{* *}$ & $108.76^{* *}$ & $276.73^{* *}$ & $9,629,107.66^{* *}$ & $33 \times 10^{-4^{* *}}$ & $99 \times 10^{-4^{* *}}$ & $49 \times 10^{-4^{* *}}$ & $0.1264^{* *}$ \\
\hline Error a & 2 & 6.67 & 0.347 & 0.673 & $3,345.48$ & $6 \times 10^{-6}$ & $6 \times 10^{-6}$ & $5 \times 10^{-6}$ & $6 \times 10^{-6}$ \\
\hline PB-F & 1 & $21,792.59^{* *}$ & $29.98^{* *}$ & $38.36^{* *}$ & $4,548,470.47^{* *}$ & $51 \times 10^{-4^{* *}}$ & $63 \times 10^{-4^{* *}}$ & $58 \times 10^{-4^{* *}}$ & $10 \times 10^{-4^{* *}}$ \\
\hline $\mathrm{FA}(\mathrm{Zn}$ and $\mathrm{B})$ & 3 & $8,884.07^{* *}$ & $138.92^{* *}$ & $61.37^{* *}$ & $1,28,3540.14^{* *}$ & $36 \times 10^{-5^{* *}}$ & $19 \times 10^{-4^{* *}}$ & $19 \times 10^{-5^{* *}}$ & $5 \times 10^{-5^{* *}}$ \\
\hline $\mathrm{L}-\mathrm{SHS} \times \mathrm{PB}-\mathrm{F}$ & 1 & $141.53^{* *}$ & $2.31^{*}$ & $0.027^{\mathrm{ns}}$ & $167,825.58^{* *}$ & $2 \times 10^{-5^{*}}$ & $4 \times 10^{-5^{* *}}$ & $24 \times 10^{-6^{*}}$ & $1 \times 10^{-5^{*}}$ \\
\hline $\begin{array}{l}\mathrm{L}-\mathrm{SHS} \times \mathrm{FA} \\
(\mathrm{Zn}, \mathrm{B})\end{array}$ & 3 & $14,401.76^{* *}$ & $41.36^{* *}$ & $7.32^{* *}$ & $1,848,486.96^{*}$ & $1 \times 10^{-5^{*}}$ & $3 \times 10^{-5^{* *}}$ & $2 \times 10^{-5^{*}}$ & $4 \times 10^{-6 \mathrm{~ns}}$ \\
\hline $\begin{array}{l}\mathrm{PB}-\mathrm{F} \times \mathrm{FA} \\
(\mathrm{Zn}, \mathrm{B})\end{array}$ & 3 & $111.87^{*}$ & $27.2^{\mathrm{ns}}$ & $4.31^{* *}$ & $638,874.08^{* *}$ & $52 \times 10^{-5^{* *}}$ & $15 \times 10^{-4 * *}$ & $74 \times 10^{-5^{* *}}$ & $7 \times 10^{-5^{* *}}$ \\
\hline $\begin{array}{l}-\mathrm{SHS} \times \mathrm{PB}- \\
\times \mathrm{FA}(\mathrm{Zn}, \mathrm{B})\end{array}$ & 3 & $154.06^{* *}$ & $12.33^{* *}$ & $0.743^{\text {ns }}$ & $16,518.91^{*}$ & $14 \times 10^{-6^{* *}}$ & $1 \times 10^{-5^{* *}}$ & $16 \times 10^{-6^{* *}}$ & $8 \times 10^{-6^{*}}$ \\
\hline Error b & 28 & 19.32 & 0.632 & 0.415 & $6,936.45$ & $7 \times 10^{-5}$ & $8 \times 10^{-5}$ & $8 \times 10^{-5}$ & $6 \times 10^{-5}$ \\
\hline
\end{tabular}

Table 2. Mean values for yield, yield components and chlorophyll fluorescence parameters, such as $F_{v} / F_{m}-$ maximal quantum yield of PSII photochemistry; $\Phi_{\text {PSII }}$ - effective quantum yield of PSII photochemistry; $\mathrm{F}_{\mathrm{v}}{ }^{\prime} / \mathrm{F}_{\mathrm{m}}{ }^{\prime}$ - efficiency of PSII in the light-adapted state; and NPQ - nonphotochemical quenching of bread wheat affected by PB-F - phosphate bio-fertilizer and FA of Zn and B - foliar application of zinc and boron under L-SHS - late-season heat stress; in a split-plot factorial design with three replications. Column means followed by the same letter are not significantly different at 0.05 probability level using LS means of SAS.

\begin{tabular}{|c|c|c|c|c|c|c|c|c|c|}
\hline Treatments & & & $\begin{array}{l}\text { Number of } \\
\text { spikes } \mathrm{m}^{-2}\end{array}$ & $\begin{array}{l}\text { Number of } \\
\text { grain spike }^{-1}\end{array}$ & $\begin{array}{l}\text { Grain yield } \\
{\left[\mathrm{kg} \mathrm{h}^{-1}\right]}\end{array}$ & $\mathrm{F}_{\mathrm{v}} / \mathrm{Fm}_{\mathrm{m}}$ & $\Phi_{P S I I}$ & $\mathrm{~F}_{\mathrm{v}}{ }^{\prime} / \mathrm{Fm}^{\prime}$ & NPQ \\
\hline L-SHS & PB-F & FA & & & & & & & \\
\hline \multirow{8}{*}{$\begin{array}{l}\text { N-HS } \\
\text { (OPD) }\end{array}$} & \multirow[t]{4}{*}{ NPB-F } & WFA & $424^{\mathrm{g}}$ & $37.6^{\mathrm{g}}$ & $4,730.67^{g}$ & $0.817^{\mathrm{def}}$ & $0.772^{\mathrm{fg}}$ & $0.803^{\text {defg }}$ & $0.347^{\mathrm{c}}$ \\
\hline & & ZnFA & $426^{\mathrm{g}}$ & $43.3^{\mathrm{de}}$ & $5,388.21^{\mathrm{f}}$ & $0.821^{\mathrm{de}}$ & $0.766^{\mathrm{gh}}$ & $0.796^{\text {fghi }}$ & $0.348^{c}$ \\
\hline & & BFA & $456^{f}$ & $34.3^{\mathrm{i}}$ & $5,379.82^{f}$ & $0.823^{\mathrm{de}}$ & $0.777^{\text {efg }}$ & $0.809^{\text {cdef }}$ & $0.349^{c}$ \\
\hline & & $\mathrm{Zn}+\mathrm{BFA}$ & $481^{d}$ & $44.3^{\mathrm{cd}}$ & $5,779.46^{\mathrm{e}}$ & $0.830^{\text {bcd }}$ & $0.803^{b c}$ & $0.813^{\text {cde }}$ & $0.352^{\mathrm{c}}$ \\
\hline & \multirow[t]{4}{*}{ PB-F } & WFA & $532^{b}$ & $45.3^{b c}$ & $5,925.53^{d}$ & $0.841^{\mathrm{abc}}$ & $0.793^{\mathrm{cd}}$ & $0.819^{b c}$ & $0.357^{\mathrm{c}}$ \\
\hline & & ZnFA & $593^{a}$ & $48.7^{\mathrm{a}}$ & $7,751.55^{\mathrm{a}}$ & $0.854^{\mathrm{a}}$ & $0.823^{\mathrm{a}}$ & $0.836^{\mathrm{a}}$ & $0.359^{c}$ \\
\hline & & BFA & $483^{d}$ & $36.3^{\mathrm{h}}$ & $6,117.66^{\mathrm{c}}$ & $0.832^{\mathrm{bcd}}$ & $0.786^{\text {def }}$ & $0.817^{\mathrm{bcd}}$ & $0.353^{c}$ \\
\hline & & $\mathrm{Zn}+\mathrm{BFA}$ & $497^{c}$ & $45.6^{\mathrm{b}}$ & $6,474.06^{b}$ & $0.841^{\mathrm{abc}}$ & $0.815^{\mathrm{ab}}$ & $0.831^{\mathrm{ab}}$ & $0.359^{c}$ \\
\hline \multirow{8}{*}{$\begin{array}{l}\mathrm{HS} \\
\text { (LPD) }\end{array}$} & \multirow[t]{4}{*}{ NPB-F } & WFA & $369^{k}$ & $35.6^{\mathrm{h}}$ & $3,464.39^{k}$ & $0.801^{\mathrm{g}}$ & $0.753^{\mathrm{hi}}$ & $0.785^{\mathrm{ij}}$ & $0.448^{\mathrm{b}}$ \\
\hline & & $\mathrm{ZnFA}$ & $370^{\mathrm{k}}$ & $40.3^{\mathrm{f}}$ & $3977.68^{j}$ & $0.802^{\mathrm{fg}}$ & $0.735^{\mathrm{j}}$ & $0.773^{\mathrm{j}}$ & $0.449^{b}$ \\
\hline & & BFA & $383^{\mathrm{j}}$ & $38.6^{\mathrm{g}}$ & $3916.34^{j}$ & $0.805^{\mathrm{fg}}$ & $0.747^{\mathrm{ij}}$ & $0.786^{\mathrm{hij}}$ & $0.451^{\mathrm{ab}}$ \\
\hline & & $\mathrm{Zn}+\mathrm{BFA}$ & $412^{\mathrm{h}}$ & $41.1^{\mathrm{f}}$ & $3978.42^{\mathrm{j}}$ & $0.811^{\mathrm{efg}}$ & $0.775^{\mathrm{efg}}$ & $0.790^{\text {ghi }}$ & $0.454^{\mathrm{ab}}$ \\
\hline & \multirow[t]{4}{*}{ PB-F } & WFA & $392^{\mathrm{i}}$ & $42.3^{\mathrm{e}}$ & $4193.78^{\mathrm{i}}$ & $0.826^{\text {cde }}$ & $0.763^{\mathrm{gh}}$ & $0.801^{\mathrm{efgh}}$ & $0.462^{\mathrm{ab}}$ \\
\hline & & $\mathrm{ZnFA}$ & $472^{\mathrm{e}}$ & $43.3^{\mathrm{de}}$ & $5843.53^{\mathrm{de}}$ & $0.843^{\mathrm{ab}}$ & $0.790^{\text {cde }}$ & $0.822^{\mathrm{abc}}$ & $0.466^{\mathrm{a}}$ \\
\hline & & BFA & $419 \mathrm{~g}^{\mathrm{h}}$ & $38.2^{\mathrm{g}}$ & $4344.33^{\mathrm{h}}$ & $0.812^{\mathrm{efg}}$ & $0.755^{\text {hi }}$ & $0.797^{\text {fghi }}$ & $0.454^{\mathrm{ab}}$ \\
\hline & & $\mathrm{Zn}+\mathrm{BFA}$ & $423^{\mathrm{g}}$ & $44.1^{\mathrm{d}}$ & $4672.48^{\mathrm{g}}$ & $0.825^{\mathrm{de}}$ & $0.786^{\mathrm{def}}$ & $0.807^{\text {cdef }}$ & $0.461^{\mathrm{ab}}$ \\
\hline
\end{tabular}


Number of grains per spike: L-SHS, PB-F, and foliar application treatments significantly affected the number of grains per spike (Table 1). L-SHS reduced the number of grains by $5.3 \%$ compared to N-HS. Nonetheless, seed inoculation with PB-F and foliar application of $\mathrm{Zn}$ and B significantly reduced the harmful effects of L-SHS on the number of grains by 15.8 and $11 \%$, respectively, compared with control (Tables 1, 2). The maximum and minimum values were obtained after the combined treatments, namely $\mathrm{PB}-\mathrm{F}+\mathrm{Zn}$ foliar application under N-HS, and NPB-F + B foliar application under N-HS (Table 2).

1,000-grain mass: L-SHS significantly reduced the 1,000 -grain mass by $12.2 \%$ (Fig. $1 A$ ). Seed inoculation with PB-F significantly increased this parameter by $6.3 \%$ (Fig. 1B). In addition, $\mathrm{Zn}$ and $\mathrm{B}$ foliar application significantly increased the 1,000-grain mass (Fig. 1C). Among the interactions of L-SHS and nutrients foliar application, the maximum and minimum 1,000-grain mass were observed after the combined treatments of N-HS $+\mathrm{B}$ foliar application, and L-SHS $+\mathrm{Zn}+\mathrm{B}$ foliar application (Fig. 1D). As well as, among the interactions of PB-F and nutrients foliar application, the maximum and minimum 1,000 -grain mass were obtained in the combined treatments of PB-F + B foliar application, and NPB-F $+\mathrm{Zn}$ $+\mathrm{B}$ foliar application (Fig. 1E).

Grain yield: L-SHS, PB-F, and foliar application treatments significantly affected the grain yield. L-SHS significantly reduced the grain yield by $26.8 \%$ compared to N-HS. However, seed inoculation with PB-F and foliar application of $\mathrm{Zn}$ and $\mathrm{B}$ significantly reduced the harmful effects of L-SHS on the grain yield by 17.4 and $12.5 \%$, respectively, compared with control (Tables 1,2). The maximum and minimum grain yield were obtained in the combined treatments namely $\mathrm{PB}-\mathrm{F}+\mathrm{Zn}$ under $\mathrm{N}-\mathrm{HS}$, and NPB-F + water foliar application under L-SHS (Table 2).

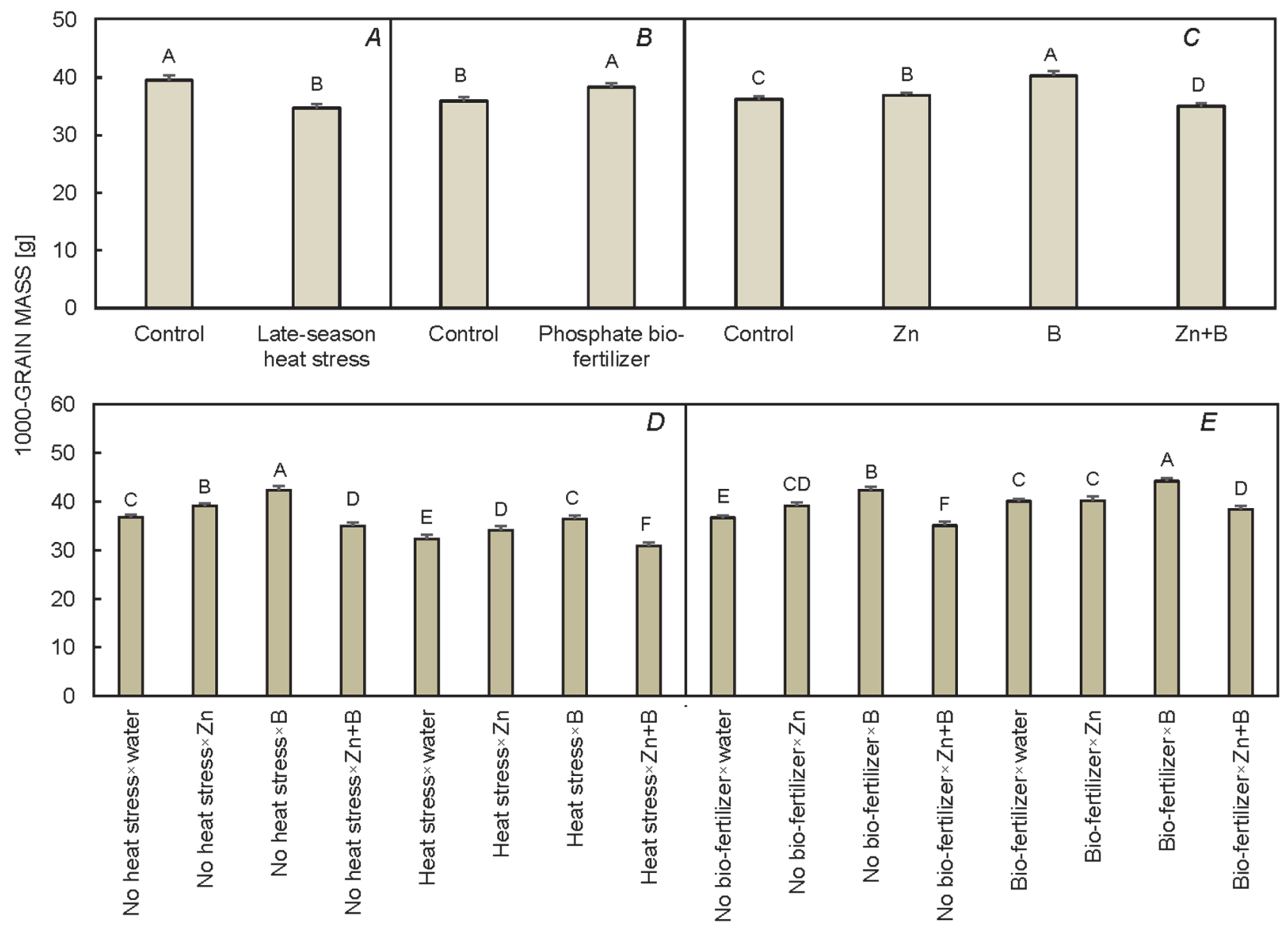

Fig. 1. Effect of LSHS $(A), \operatorname{PBF}(B), \mathrm{Zn}$ and B foliar application $(C)$, interaction of LSHS with foliar application of $\mathrm{Zn}$ and $\mathrm{B}(D)$ and interaction of $\mathrm{PBF}$ with foliar application of $\mathrm{Zn}$ and $\mathrm{B}(E)$ on 1000-grain mass of bread wheat. 


\section{Chl fluorescence parameters}

$\mathbf{F}_{\mathbf{v}} / \mathbf{F}_{\mathbf{m}}$ : L-SHS significantly reduced the $\mathrm{F}_{\mathrm{v}} / \mathrm{F}_{\mathrm{m}}$ by $2 \%$. However, seed inoculation with PB-F and application of $\mathrm{Zn}$ and $\mathrm{B}$ enhanced $\mathrm{F}_{\mathrm{v}} / \mathrm{F}_{\mathrm{m}}$ under L-SHS (Table 2). The maximum and minimum of $\mathrm{F}_{\mathrm{v}} / \mathrm{F}_{\mathrm{m}}$ was obtained in the combined treatments, namely $\mathrm{PB}-\mathrm{F}+\mathrm{Zn}$ foliar application under N-HS, and NPB-F + water foliar application under L-SHS (Table 2).

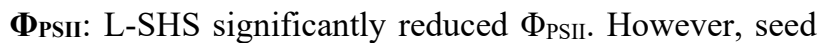
inoculation with PB-F mitigated the effects of L-SHS on the $\Phi_{\text {PSII }}$ by $1.3 \%$, but $\mathrm{Zn}$ and $\mathrm{B}$ application was not effective (Tables 1, 2). The maximum and minimum $\Phi_{\text {PSII }}$ was obtained in the combined treatments namely PB-F + $\mathrm{Zn}$ foliar application under N-HS, and NPB-F $+\mathrm{Zn}$ foliar application under L-SHS (Table 2).

\section{Discussion}

The results in the current study have showed that the L-SHS, as a result of a delay in planting, significantly reduced the number of spikes, number of grains, 1,000grain mass, and grain yield of bread wheat. In wheat, high temperature stress during reproductive development is a primary constraint to its production. Accumulation of ROS as a result of high temperature stress is a major cause of loss of crop productivity globally (Khan and Sing 2008, Gill et al. 2010). Formation of ROS is related to ethylene production and lipid peroxidation and results in membrane fluidity (Weckx et al. 1989). Increased ethylene has been shown in mature wheat plants to shorten the grain filling period, reduce 1,000-grain mass, hasten maturity, trigger premature senescence, and finally reduce the grain yield (Beltrano et al. 1999). Therefore, the cause of reduced yield and yield components of bread wheat under L-SHS can be due to the formation of ROS and subsequently ethylene production. Moreover, other researchers reported that grain filling period coincided with L-SHS due to delay in planting; resulting in decreasing yield and yield components of wheat (Ayeneh et al. 2002, Moshatati et al. 2012), which confirms the results of this experiment. Xiao et al. (2009) showed that if the temperature rises by $0.5-2.5^{\circ} \mathrm{C}$, the yield of spring wheat decreases by $16.5-18.5 \%$. Moreover, it was reported that when the temperature increased by $1.0-2.5^{\circ} \mathrm{C}$, the number of grains per spike and 1,000-grain mass decreased in spring wheat by $1.0-5.0$, and $1.3-8.8 \mathrm{~g}$, respectively (Zhang and Deng 2008). It can be due to negative effects of L-SHS causing shorter growth period, which leads to reduced dry matter accumulation and transfer, and decreases bread wheat yield. In addition, the L-SHS reduced the values of Chl fluorescence parameters, such as $\mathrm{F}_{\mathrm{v}} / \mathrm{F}_{\mathrm{m}}, \Phi_{\mathrm{PSII}}, \mathrm{F}_{\mathrm{v}}{ }^{\prime} / \mathrm{F}_{\mathrm{m}}{ }^{\prime}$, indicating that a structural and functional disorder of the photosynthetic apparatus and damage to the PSII had occurred (Pereira et al. 2000, Murkowski 2001). Reductions in the $\mathrm{F}_{\mathrm{v}} / \mathrm{F}_{\mathrm{m}}, \Phi_{\mathrm{PSII}}$, and $\mathrm{F}_{\mathrm{v}}{ }^{\prime} / \mathrm{F}_{\mathrm{m}}{ }^{\prime}$ under L-SHS suggested that an important portion of the PSII reaction
$\mathbf{F}_{\mathbf{v}}{ }^{\prime} / \mathbf{F}_{\mathbf{m}}{ }^{\prime}:$ L-SHS significantly reduced $\mathrm{F}_{\mathrm{v}}{ }^{\prime} / \mathrm{F}_{\mathrm{m}}{ }^{\prime}$. However, seed inoculation with $\mathrm{PB}-\mathrm{F}$ improved $\mathrm{F}_{\mathrm{v}}{ }^{\prime} / \mathrm{F}_{\mathrm{m}}{ }^{\prime}$ by $2 \%$ under L-SHS, but $\mathrm{Zn}$ and $\mathrm{B}$ was not effective in reducing the harmful effects of L-SHS on $\mathrm{F}_{\mathrm{v}}{ }^{\prime} / \mathrm{F}_{\mathrm{m}}{ }^{\prime}$ (Tables 1,2$)$. The maximum and minimum $\mathrm{F}_{\mathrm{v}}{ }^{\prime} / \mathrm{F}_{\mathrm{m}}{ }^{\prime}$ was obtained in the combined treatments, namely $\mathrm{PB}-\mathrm{F}+\mathrm{Zn}$ foliar application under N-HS, and NPB-F + Zn foliar application under L-SHS (Table 2).

NPQ: L-SHS increased the value of NPQ by $22.5 \%$. Nonetheless, seed inoculation with $\mathrm{PB}-\mathrm{F}$ and $\mathrm{Zn}$ and $\mathrm{B}$ foliar application increased NPQ under L-SHS conditions (Table 2). The maximum and minimum value of NPQ was obtained in the combined treatments, namely PB-F and $\mathrm{Zn}$ foliar application under L-SHS, and NPB-F + water foliar application under N-HS (Table 2).

centre was damaged under L-SHS. These damages were associated with structural modifications on PSII, especially in D1 protein, which under conditions of heat stress was phosphorylated and degraded afterwards (Asada et al. 1998). Furthermore, reduction in the $\mathrm{F}_{\mathrm{v}} / \mathrm{F}_{\mathrm{m}}, \Phi_{\text {PSII }}$, and $\mathrm{F}_{\mathrm{v}}{ }^{\prime} / \mathrm{F}_{\mathrm{m}}$ ' also suggested the occurrence of photoinhibition and photodamage (Colom and Vazzana 2003). When this occurs, accumulation of reduced electron acceptors may increase the generation of ROS, which can induce oxidative injuries (Souza et al. 2004). These oxidative injuries could enhance $\mathrm{Chl}$ degradation or the inhibition of its biosynthesis (Papadakis et al. 2004), damage PSII components (Souza et al. 2004), inactivate many chloroplast enzymes, especially, those participating in $\mathrm{CO}_{2}$ assimilation (Dekov et al. 2000). It could further explain the reductions in $\mathrm{F}_{\mathrm{v}} / \mathrm{F}_{\mathrm{m}}, \Phi_{\mathrm{PSII}}$, and $\mathrm{F}_{\mathrm{v}}{ }^{\prime} / \mathrm{F}_{\mathrm{m}}{ }^{\prime}$ in the high temperature-stressed wheat plant in the present study. It was also observed that the L-SHS increased the value of NPQ. It seems that such an increase in NPQ may be a mechanism to downregulate photosynthetic electron transport so that production of ATP and NADPH would be in equilibrium with the decreased demand in the Calvin cycle in heat-treated leaves and to also avoid over-reduction of $\mathrm{Q}_{\mathrm{A}}$ (Bukhov et al. 1998). Lu and Zhang (2000) showed that under heat-stress conditions, the decrease in $\mathrm{F}_{\mathrm{v}}{ }^{\prime} / \mathrm{F}_{\mathrm{m}}{ }^{\prime}$ and $\Phi_{\text {PSII }}$ was associated with a decrease in $\mathrm{F}_{\mathrm{v}} / \mathrm{F}_{\mathrm{m}}$, and the decrease in $\mathrm{F}_{\mathrm{v}} / \mathrm{F}_{\mathrm{m}}$ occurred due to a decrease in the OEC activity and an inhibition of electron transport at the PSII acceptor side. Increase in NPQ results in a decrease in $\mathrm{F}_{\mathrm{v}}{ }^{\prime} / \mathrm{F}_{\mathrm{m}}{ }^{\prime}$ (Demmig-Adams et al. 1996). Therefore, the decrease in $\mathrm{F}_{\mathrm{v}} / \mathrm{F}_{\mathrm{m}}, \Phi_{\text {PSII }}, \mathrm{F}_{\mathrm{v}}{ }^{\prime} / \mathrm{F}_{\mathrm{m}}{ }^{\prime}$ under L-SHS was a result of the increased nonphotochemical dissipation of excitation energy. Seed inoculation with PB-F significantly increased the number of spikes, number of grains per spike, 1,000-grain mass, yield and yield components of bread wheat under both N-HS and L-SHS conditions.

It was observed that seed inoculation with PB-F increased the number of grains per spike by 17 and $15.8 \%$ 
in both N-HS and L-SHS conditions, respectively, which could be the main reason for increase in wheat yield in this study. $\mathrm{P}$ is a component of nucleic acids and cellular membranes, and essential for metabolic processes and photosynthesis (Vance et al. 2003) and also for its role in reduction of ROS during environmental stresses (Wu et al. 2005, Behl et al. 2003). Therefore, increasing wheat yield is expected due to the using PB-F under L-SHS conditions. Decreases in plant yield due to nutrient stress including $\mathrm{P}$ have been previously reported in other crops and can be attributed to the limited availability of the plant resources such as phosphorus and decreased overall photosynthesis (Singh et al. 2013). Nezarat and Gholami (2009) attributed the increase in grain yield to bacteria existing in PB-F, such as Bacillus and Pseudomonas, which are able to enhance $\mathrm{P}$ solubility of rock phosphate and increase its availability for wheat by oxidizing $\mathrm{P}$ and decrease soil $\mathrm{pH}$. Moreover, seed inoculation with PB-F increased the values of Chl fluorescence parameters, such as $\mathrm{F}_{\mathrm{v}} / \mathrm{F}_{\mathrm{m}}, \Phi_{\mathrm{PSII}}$, $\mathrm{F}_{\mathrm{v}}{ }^{\prime} / \mathrm{F}_{\mathrm{m}}{ }^{\prime}$, and $\mathrm{NPQ}$, which might be related to the regulatory role of $\mathrm{P}$ in $\mathrm{CO}_{2}$ assimilation pathway, increase in the amount and activity of Rubisco, and ribulose-1,5bisphosphate (RuBP) regeneration capacity (Fleisher et al. 2012). Shool and Shamshiri (2014) reported that the use of bio-fertilizer containing phosphate-solubilizing bacteria increased the values of $\mathrm{Chl}$ fluorescence parameters, such as $\mathrm{F}_{\mathrm{v}} / \mathrm{F}_{\mathrm{m}}, \Phi_{\mathrm{PSII}}$, and $\mathrm{F}_{\mathrm{v}}{ }^{\prime} / \mathrm{F}_{\mathrm{m}}{ }^{\prime}$. Xu et al. (2007) showed that the NPQ decreased in plants under $\mathrm{P}$ deficiency conditions. Severe decrease of Chl fluorescence parameters, such as $\mathrm{F}_{\mathrm{v}} / \mathrm{F}_{\mathrm{m}}, \mathrm{F}_{\mathrm{v}}{ }^{\prime} / \mathrm{F}_{\mathrm{m}}{ }^{\prime}, \Phi_{\mathrm{PSII}}$, and electron transport rate $\left(\mathrm{J}_{\mathrm{F}}\right)$ under $\mathrm{P}$ deficiency suggested the occurrences of excess energy dissipation by NPQ or non-radiative mechanisms in the PSII reaction center (Singh and Reddy 2015). Photosynthetic processes are dependent on the phosphate precursors, inorganic phosphate or phosphorylated intermediates, such as ADP, ATP, $\operatorname{NADP}(\mathrm{H})$ and sugar phosphates, essential for energy transfer. Therefore, $\mathrm{P}$ deficiency affects plant photosynthetic capacity due to its direct effect on the tissue $\mathrm{P}$ status and especially phosphorus homeostasis in the cytosol and chloroplasts (Warren 2011). Among nutrients foliar application treatments, the combined $\mathrm{Zn}+\mathrm{B}$ was more effective to reduce harmful effects of L-SHS. However, among the combined application nutrients FA + PB-F, Zn separate application influenced more improvement of $\mathrm{Chl}$ fluorescence parameters and increase of yield and yield components of bread wheat under L-SHS.

Current study revealed that the combined application of $\mathrm{Zn}$ and $\mathrm{B}$ compared to $\mathrm{Zn}$ separate application increased number of spikes by $10.9 \%$ under L-SHS, however, combined application of $\mathrm{PB}-\mathrm{F}+\mathrm{Zn}$ was more effective for yield improvement. Also, the $\mathrm{PB}-\mathrm{F}+\mathrm{Zn}$ treatment induced the highest $\mathrm{Chl}$ fluorescence parameters, such as $\mathrm{F}_{\mathrm{v}} / \mathrm{F}_{\mathrm{m}}$, $\mathrm{F}_{\mathrm{v}}{ }^{\prime} / \mathrm{F}_{\mathrm{m}}{ }^{\prime}, \Phi_{\mathrm{PSII}}$, and NPQ, under L-SHS and OPD conditions, which can justify the increase of the grain yield as a result of the combined application of these treatments compared to the combined application of $\mathrm{Zn}$ and B. Mohammadi
(2017) reported that PB-F and $\mathrm{Zn}$ interaction could increase grain yield by increasing nutrient availability, leaf area index, Chl content, photosynthesis, growth hormones, and creating favorable growth conditions. As already mentioned, one of the main reasons for the loss of yield and damage to the photosynthetic apparatus under heat stress conditions is the accumulation of ROS. Therefore, any factor that reduces ROS damage can help to increase the yield and improve the $\mathrm{Chl}$ fluorescence parameters. $\mathrm{Zn}$ plays an important role in lowering ROS generation and defending cells against ROS attack, while Zn deficiency can induce higher contents of ROS causing plant damage (Cakmak 2000). It has been reported that the primary physiological role of $\mathrm{Zn}$ is activating antioxidative mechanisms of crops against biotic and abiotic stresses (Marschner 1995). Yavas and Unay (2016) reported that foliar application of $\mathrm{Zn}$ resulted in a significant increase in antioxidant enzyme activities in response to stress, which could be one of the main reasons for improving the $\mathrm{Chl}$ fluorescence parameters and increasing wheat yield by $\mathrm{Zn}$ application in this study. Furthermore, Chl synthesis is improved by $\mathrm{Zn}$, which acts as a structural and catalytic component of proteins, enzymes, and as co-factor for normal development of pigment biosynthesis (Balashouri 1995). In addition, $\mathrm{Zn}$ is known to have a stabilizing and protective effect on biomembranes; improving the integrity of biomembranes may improve photosynthesis under stress conditions (Cakmak 2000). Furthermore, Zn exerts a key function in cell membrane by protecting sulfhydryl groups in membrane proteins from oxidation by free radical groups (Cakmak et al. 1996).

In this experiment, it was observed that B foliar application increased the grain yield by 12.1 and $11.5 \%$ under both N-HS and L-SHS conditions, respectively. The reason for this increase can be attributed to an increase of 7.0 and $3.7 \%$ in the number of spikes under both N-HS and L-SHS conditions, respectively. B is directly or indirectly involved in several physiological and biochemical processes during plant growth such as cell elongation, cell division, cell wall biosynthesis, membrane function, nitrogen metabolism, leaf photosynthesis, and uracil synthesis (Marschner 1995). B application induces changes in carbohydrate metabolism (Camacho-Cristobal and Gonzalez-Fontes 1999), which in turn is responsible for the decrease in concentration of phenolic compounds in leaves (Blevins and Lukaszewski 1998). The low content of these phenolics oxidized to derivatives such as quinones, reduce the production of extremely ROS and cause reduction in peroxidative damage to vital components of cell membrane such as lipids and proteins, which eventually leads to repair of several cellular functions (Cakmak and Römheld 1997, El-Shintinawy 1999), Therefore, B may also protect plasma membrane against peroxidative damage by toxic $\mathrm{O}_{2}$ species. $\mathrm{B}$ nutrition improves sugar transport in the plant, which helps to improve seed germination and grain formation. This in turn improves the yield by improving the temperature 
stress (Waraich et al. 2011).

Many researchers have reported the positive effects of $\mathrm{Zn}$ and $\mathrm{B}$ foliar application on increase yield and yield component (Ali et al. 2009) and improve values of Chl fluorescence parameters such as $\mathrm{F}_{\mathrm{v}} / \mathrm{F}_{\mathrm{m}}, \Phi_{\mathrm{PSII}}, \mathrm{F}_{\mathrm{v}}{ }^{\prime} / \mathrm{F}_{\mathrm{m}}{ }^{\prime}$, and NPQ under stress conditions (Graham and McDonald 2001, Wang and Jin 2007, Guidi et al. 2011). Generally, the results obtained by the above researchers were observed only in the combined application of these elements with PB-F but were not observed in the micronutrient separate application.

Conclusions: The results of the present study indicate that seed inoculation with $\mathrm{PB}-\mathrm{F}$ rather than $\mathrm{Zn}$ and $\mathrm{B}$ foliar

\section{References}

Abdoli M., Esfandiari E., Mousavi B., Sadeghzadeh, B.: Effects of foliar application of zinc sulfate at different phenological stages on yield formation and grain zinc content of bread wheat (cv. Kohdasht). - Azarian J. Agri. 1: 11-17, 2014.

Ahmed M., Farooq S.: Growth and physiological responses of wheat cultivars under various planting windows. - J. Anim. Plant Sci. 23: 1407-1414, 2013.

Ali S., Shah A., Arif M. et al.: Enhancement of wheat grain yield components through foliar application of zinc and boron. Sarhad J. Agri. 25: 15-19, 2009.

Asad A., Rafique R.: Effect of zinc, copper, manganese and boron on the yield and yield components of wheat crop in Tehsil Peshawar. - Pak. J. Biol Sci. 3: 1615-1620, 2000.

Asada K., Endo T., Mano J., Miyake C.: Molecular mechanism for relaxation of and protection from light stress. - In: Saton K., Murata N. (ed.): Stress Responses of Photosynthetic Organisms. Pp. 37-52. Elsevier, Amsterdam 1998.

Ayeneh A., van Ginkel M., Reynolds M.P., Ammar K.: Comparison of leaf, spike, peduncle and canopy temperature depression in wheat under heat stress. - Field Crop. Res. 79: 173-184, 2002.

Balashouri P.: Effect of zinc on germination, growth, pigment content and phytomass of Vigna radiata and Sorghum bicolor. - J. Ecobiol. 7: 109-114, 1995.

Bangladesh Agricultural Research Institute (BARI): Annual Report, 2005-2006. Pp. 30. Joydebpur, Gazipur, Dhaka, Bangladesh 2006.

Behl R.K., Sharma H., Kumar V., Singh K.P.: Effect of dual inoculation of V A micorrhyza and Azotobacter chroococcum on above flag leaf characters in wheat. - Agron Soil Sci. 49: 25-31, 2003.

Beltrano J., Ronco M.G., Montaldi E.R.: Drought stress syndrome in wheat is provoked by ethylene evolution imbalance and reversed by rewatering, aminoethoxyvinylglycine and sodium benzoate. - J. Plant Growth Regul. 18: 59-64, 1999.

Blevins D.G., Lukaszewski K.M.: Boron in plant structure and function. - Annu. Rev. Plant Phys. 49: 481-500, 1998.

Bukhov N.G., Boucher N., Carpentier R.: Loss of the precise control of photosynthesis and increased yield of non-radiative dissipation of excitation energy after mild treatment of barley leaves. - Physiol. Plantarum 104: 563-570, 1998.

Cakmak I., Sary N., Marschner H. et al.: Dry matter production and distribution of $\mathrm{Zn}$ in bread and durum wheat genotypes application was more effective in reducing the harmful effects of L-SHS on chlorophyll fluorescence, yield, and yield components of common bread wheat. $\mathrm{Zn}+\mathrm{B}$ combined application, rather than their separate application, was more effective to improve chlorophyll fluorescence parameters, yield, and yield components of common bread wheat under both N-HS and L-SHS conditions. In general, it can be concluded that the optimum planting date (21 November), seed inoculation with PB-F and Zn + B combined application are three appropriate management strategies to improve the chlorophyll fluorescence parameters and increase yield and yield components of bread wheat (Triticum aestivum L.) in Mediterranean climates such as the southwestern part of Iran (Khouzestan province).

differing in Zn efficiency. - J. Plant Soil 180: 173-181, 1996.

Cakmak I., Römheld V.: Boron deficiency-induced impairments of cellular functions in plants. - Plant Soil 193: 71-83, 1997.

Cakmak I.: Tansley Review No. 111 - possible roles of zinc in protecting plant cell from damage by reactive oxygen species. - New Phytol. 146: 185-205, 2000.

Camacho-Cristobal J.J., Gonzales-Fontes A.: Boron deficiency causes a drastic decrease in nitrate content and nitrate reductase activity, and increases the content of carbohydrates in leaves from tobacco plants. - Planta 209: 528-536, 1999.

Colom M.R., Vazanna C.: Photosynthesis and PSII functionality of drought-resistant and drought-sensitive weeping lovegrass plants. - Environ. Exp. Bot. 49: 135-144, 2003.

Dekov I., Tsonev T., Yordanov I.: Effects of water stress and high temperature stress on the structure and activity of photosynthetic apparatus of Zea mays and Helianthus annuus. Photosynthetica 38: 361-366, 2000.

Demmig-Adams B., Adams W.W.: Photoprotection and other responses of plants to high light stress. - Annu. Rev. Plant Phys. 43: 599-626, 1992.

Demmig-Adams B., Adams W.W., Barker D.H. et al.: Using chlorophyll fluorescence to assess the fraction of absorbed light allocated to thermal dissipation of excess excitation. - Physiol. Plantarum 98: 253-264, 1996.

Ehteshami S.M.R., Aghaalikhani M., Khavazi K., Chaichi M.R.: Effect of phosphate solubilizing microorganisms on quantitative and qualitative characteristics of maize (Zea mays L.) under water deficit stress. - Pak. J. Biol. Sci. 10: 3585-3591, 2007.

El-Shintinawy F.: Structural and functional damage caused by boron deficiency in sunflower leaves. - Photosynthetica 36: 565-573, 1999.

Fleisher D.H., Wang Q., Timlin D.J. et al.: Response of potato gas exchange and productivity to phosphorus deficiency and carbon dioxide enrichment. - Crop Sci. 52: 1803-1815, 2012.

Gill S.S., Khan N.A., Anjum N.A., Tuteja N.: Amelioration of cadmium stress in crop plants by nutrients management: Morphological, physiological and biochemical aspects. - Plant Stress 5: 1-23, 2010.

Gholinezhad E., Aynaband A., Hassanzade A. et al.: Study of the effect of drought stress on yield, yield components and harvest index of sunflower hybrid iroflor at different levels of nitrogen and plant population. - Not. Bot. Horti. Agrobo. 37: 85-94, 2009. 
Graham A.W., McDonald G.K.: Effect of zinc on photosynthesis and yield of wheat under heat stress. - In: Proceedings of the $10^{\text {th }}$ Australian Agronomy Conference 2001. Australian Society of Agronomy. Hobart, Tasmania 2001.

Guidi L., Degl'Innocenti E., Carmassi G. et al.: Effects of boron on leaf chlorophyll fluorescence of greenhouse tomato grown with saline water. - Environ Exp. Bot. 73: 57-63, 2011.

Hassan I.A.: Effects of water stress and high temperature on gas exchange and chlorophyll fluorescence in Triticum aestivum L. - Photosynthetica 44: 312-315, 2006.

Ivanov A., Hurry V., Sane P. et al.: Reaction centre quenching of excess light energy and photoprotection of photosystem II. - J. Plant Biol. 51: 85-96, 2008.

Jafari Moghadam M., Heidari Sharifabad H., Noormohamadi G. et al.: The effect of zinc, boron and copper foliar application, on yield and yield components in wheat (Triticum aestivum L.). - Ann. Biol. Res. 3: 3875-3884, 2012.

Keleş Y., Ergün N., Öncel I.: Antioxidant enzyme activity affected by high boron concentration in sunflower and tomato seedlings. - Commun. Soil Sci. Plant 42: 173-183, 2011.

Khan N.A., Singh S.: Abiotic Stress and Plant Responses. Pp. 205-215. IK International, New Delhi 2008.

Lu C.M., Zhang J.H.: Heat-induced multiple effects on PSII in wheat plants. - J. Plant Physiol. 156: 259-265, 2000.

Marschner H.: Mineral Nutrition of Higher Plants, $2^{\text {nd }}$ ed. Pp. 85131. Academic Press, New York 1995.

Modhej A., Naderi A., Emam Y. et al.: Effects of post-anthesis heat stress and nitrogen levels on grain yield in wheat ( $T$. durum and T.aestivum) cultivars. - Int. J. Plant Prod. 2: 254-267, 2008.

Mohammadi K.: Phosphorus solubilizing bacteria: occurrence, mechanisms and their role in crop production. - Res. Environ. 2: 80-85, 2012.

Mohammadi M.: Effect of phosphate and zinc biofertilizers on seed yield and molar ratio of phytic acid to zinc in two cultivars of bean (Phaseolus vulgaris L.). - Int. J. Agri. Biosyst. Eng. 11: 66-71, 2017.

Moshatati A., Siadat S.A., AlamiSaeid K.H. et al.: Effect of terminal heat stress on yield and yield components of spring bread wheat cultivars in Ahvaz. - Iran. Int. J. Agri. 2: 844-849, 2012.

Mousavi S.R., Galavi M., Ahmadvand G.: Effect of zinc and manganese foliar application on yield, quality and enrichment on potato. - Asian J. Plant Sci. 6: 1256-1260, 2007.

Murkowski A.: Heat stress and spermidine, effect on chlorophyll fluorescence in tomato plants. - Biol. Plantarum 44: 53-57, 2001.

Netto A.T., Campostrini E., de Oliveira J.G., Bressan-Smith R.E.: Photosynthetic pigments, nitrogen, chlorophyll a fluorescence and SPAD-502 readings in coffee leaves. - Sci. Hortic.-Amsterdam 104: 199-209, 2005.

Nezarat S., Gholami A.: The effect of co-inoculation of Azospirillum and Psedomonas rhizobacteria on nutrient of maize (Zea mays L.). - J. Agron. Crop Sci. 1: 25-32, 2009.

Olsen S.R., Cole C.V., Watanabe F.S., Dean L.A.: Estimation of Available P in Soils by Extraction with Sodium Bicarbonate. Circular 939. U.S. Department of Agriculture, Washington D.C. 1954.

Page A.L., Miller R.H., Keeney D.R.: Methods of Soil Analysis, part 2, $2^{\text {nd }}$ ed. Pp. 1159. American Society of Agronomy Soil Science Society of America, Madison 1982.

Papadakis I.E., Dimassi K.N., Bosabalidis A.M. et al.: Effects of $\mathrm{B}$ excess on some physiological and anatomical parameters of 'Navelina' orange plants grafted on two rootstocks. - Environ.
Exp. Bot. 51: 247-257, 2004

Pereira W.E., de Siqueira D.L., Martínez C.A., Puiatti M.: Gas exchange and chlorophyll fluorescence in four citrus rootstocks under aluminium stress. - J. Plant Physiol. 157: 513-520, 2000. Prasad P.V., Pisipati S.R., Momčilović I., Ristic Z.: Independent and combined effects of high temperature and drought stress during grain filling on plant yield and chloroplast EF-Tu expression in spring wheat. - J. Agron. Crop Sci. 197: 430-441, 2011.

Radmehr M.: Effect of Heat Stress on Physiology of Growth and Development of Wheat. Pp. 201. Ferdowsi University Press, Mashhad 1997.

Shool A., Shamshiri M.H.: Effect of arbuscular mycorrhizal fungi and Pseudomonas fluorescence on chlorophyll fluorescence and photosynthetic pigments of pistachio seedlings (Pistacia vera cv. Qazvini) under four water regimes. - Eur. J. Exp. Bio. 4: 246-252, 2014.

Singh S.K., Badgujar G., Reddy V.R. et al.: Carbon dioxide diffusion across stomata and mesophyll and photo-biochemical processes as affected by growth $\mathrm{CO}_{2}$ and phosphorus nutrition in cotton. - J. Plant Physiol. 170: 801-813, 2013.

Singh S.K., Reddy V.R.: Methods of mesophyll conductance estimation: its impact on key biochemical parameters and photosynthetic limitations in phosphorus stressed soybean across $\mathrm{CO}_{2}$. - Physiol. Plantarum 157: 234-254, 2016.

Singh S.K., Reddy V.R.: Response of carbon assimilation and chlorophyll fluorescence to soybean leaf phosphorus across $\mathrm{CO}_{2}$ : Alternative electron sink, nutrient efficiency and critical concentration. - J. Photoch. Photobio. B 151: 276-284, 2015.

Souza R. Machadoa E.C., Silva J.A.B. et al.: Photosynthetic gas exchange, chlorophyll fluorescence and some associated metabolic changes in cowpea (Vigna unguiculata) during water stress and recovery. - Environ. Exp. Bot. 51: 45-56, 2004.

Sparks D.L., Fendorf S.E., Toner C.V., Carski T.H.: Methods of Soil Analysis, Part 3 - Chemical Methods. Pp. 1275-1307. Soil Science Society of America Inc. American Society of Agronomy, Inc. Madison 1996.

Torun A., Gültekin I.G.Ã., Kalayci M. et al.: Effects of zinc fertilization on grain yield and shoot concentrations of zinc, boron, and phosphorus of 25 wheat cultivars grown on a zincdeficient and boron-toxic soil. - J. Plant Nutr. 24: 1817 -1829, 2001.

van Kooten O., Snel J.F.: The use of chlorophyll fluorescence nomenclature in plant stress physiology. - Photosynth. Res. 25: 147-150, 1990.

Vance C.P., Uhde-Stone C., Allan D.L.: Phosphorus acquisition and use: critical adaptations by plants for securing a nonrenewable resource. - New Phytol. 157: 423-447, 2003.

Wang H., Jin J.Y.: Effects of zinc deficiency and drought on plant growth and metabolism of reactive oxygen species in maize (Zea mays L.). - Agr. Sci. China 6: 988-995, 2007.

Waraich E.A., Ahmad R., Ashraf M. et al.: Improving agricultural water use efficiency by nutrient management in crop plants. - Acta Agr. Scand.B - S.P. 61: 291-304, 2011.

Warren C.R.: How does P affect photosynthesis and metabolite profiles of Eucalyptus globulus? - Tree Physiol. 31: 727-739, 2011.

Weckx J., Van Gronnsveld J., Vanpoucke M.: Effect of paraquat on ethylene biosynthesis by intact green Phaseolus vulgaris seedlings. - Physiol. Plantarum 75: 340-345, 1989.

Wolf B.: Improvement in the azomethine- $\mathrm{H}$ method for the determination of boron. - Commun. Soil Sci. Plan. 5: 39-44, 1974. 
Wu B., Cao S.C., Li Z.H. et al.: Effects of bioferilizer containing $\mathrm{N}$-fixr, $\mathrm{P}$ and $\mathrm{K}$ solubilizer and $\mathrm{AM}$ fungi on maize growth. Geoderma 125: 155-162, 2005.

Xiao G.J., Zhang Q., Wang R.Y.: Effects of temperature increase on wheat production in a semiarid region of China. - Air Soil Water Res. 2: 31-39, 2009.

Xu H.X., Weng X.Y., Yang Y.: Effect of phosphorus deficiency on the photosynthetic characteristics of rice plants. - Russ. J. Plant Physl+ 54: 741-748, 2007.

Yavas I., Unay A.: Effects of zinc and salicylic acid on wheat under drought stress. - J. Anim. Plant Sci. 26: 1012-1018,
2016.

Yordanov I., Velikova V., Tsonev T.: Plant responses to drought, acclimation, and stress tolerance. - Photosynthetica 38: 171$186,2000$.

Zhang C.X., Fu G.F., Yang X.Q. et al.: Heat stress effects are stronger on spikelets than on flag leaves in rice due to differences in dissipation capacity. - J. Agron. Crop Sci. 202: 394-408, 2016.

Zhang Q., Deng Z.: Impact of global climate change on the agriculture in Northwest China. - Acta Ecol. Sin. 28: 1210$1218,2008$. 